\title{
Діяльність центру дитячої фтизіохірургії
}

\author{
Фещенко Ю.І., Опанасенко М.С., Терешкович О.В., Шалагай С.М.
}

ДУ «Національний інститут фтизіатрії і пульмонології ім. Ф.Г. Яновського НАМН України», м. Київ, Україна

Обґрунтування. В Україні є відділення дитячої фтизіатрії, але не було жодного спеціалізованого дитячого фтизіохірургічного відділення. У 2019 р. в Національному інституті фтизіатрії і пульмонології (НІФП) створено центр дитячої фтизіохірургії.

Мета. Представити власний досвід і результати хірургічного лікування дітей, прооперованих у центрі дитячої фтизіохірургії НІФП.

Матеріали та методи. Повідомляється про результати хірургічного лікування 58 дітей, прооперованих із січня 2018 по січень 2021 р. Пацієнти були віком від 4 до

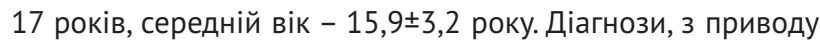
яких виконували операції: туберкульоз легень - 25 (43,1 \%), периферичний лімфаденіт - 4 (6,9%), саркоїдоз - 2 (3,4 \%), внутрішньолегенева секвестрація - 2 (3,4 \%), гістіоцитоз X - 1 (1,7 \%), гіперсенситивний пневмоніт - 1 (1,7 \%), кістозна гіпоплазія частки легені - 1 (1,7\%), неспецифічний плеврит - 2 (3,4 \%), специфічний плеврит - 2 (3,4 \%), емпієма плеври - 1 (1,7 \%), бульозна хвороба - 2 (3,4 \%), лімфома з ураженням легені - 2 (3,4 \%), ретенційні кісти 1 (1,7 \%), абсцес легені - 1 (1,7 \%), новоутворення легені 6 (10,3 \%), новоутворення грудної стінки - 1 (1,7 \%), стороннє тіло бронха - 1 (1,7 \%), ентерогенна кіста середостіння - 1 (1,7 \%), хвороба Кастлемана - 1 (1,7 \%). Виконано 60 операцій відкритим і відеоасистованим (VATS) шляхом. VATS-операції: біопсія внутрішньогрудних лімфовузлів 4 (6,7 \%), біопсія плеври - 4 (6,7 \%), парієтальна плевректомія - 2 (3,3 \%), резекція верхньої частки - 2 (3,3 \%), резекція нижньої частки - 3 (5,0 \%), резекція S1-S2 - 1 (1,7 \%), резекція S6 - 3 (5,0 \%), часткова резекція S1 і S6 із булами 1 (1,7 \%), біопсія новоутворення легені - 3 (5,0%), однопортова біопсія утворення грудної стінки - 1 (1,7 \%), парієтальна плевректомія з резекцією верхівки легені - 1 (2,9 \%), VATS праворуч із конверсією в торакотомію й субтотальним видаленням VI ребра та навколишніх м'яких тканин 1 (1,7 \%), санація плевральної порожнини - 3 (5,0 \%), ревізія плевральної порожнини із заключним гемостазом - 1 (1,7 \%). Відриті операції: пульмонектомія з приводу міофібробластичної пухлини легені - 1 (1,7 \%), резекція нижньої частки 4 (6,7 \%), резекція верхньої частки - 2 (3,3 \%), резекція базальних сегментів легені - 1 (1,7 \%), резекція S1-S2 легені - 1 (1,7 \%), резекція S6 - 1 (1,7\%), атипова резекція S8 1 (1,7 \%), плевректомія - 3 (5,0 \%), біопсія периферичного лімфовузла - 2 (3,3%), встановлення імплантованої системи для тривалих інфузій - 5 (8,3\%), її видалення 4 (6,7 \%), дренування за Бюлау - 1 (1,7 \%), біопсія аксилярного лімфовузла - 1 (1,7 \%), видалення новоутворення кореня лівої легені з медіастинальною лімфодисекцією 1 (1,7 \%), біопсія шкіри - 1 (1,7 \%), видалення кісти заднього середостіння з ушиванням стравоходу - 1 (1,7 \%).

Результати. Покращення клінічного стану й позитивна рентгенологічна динаміка спостерігалися в 57 (98,3 \%) хворих. Рівень післяопераційних ускладнень становив 8,3 \%. Інтраопераційні ускладнення: післяопераційна кровотеча 3 випадки (5,0%), пошкодження стравоходу - 1 (1,7 \%), неспроможність кукси бронха - 1 (1,7 \%).

Висновки. Хірургічне втручання в дітей, хворих на туберкульоз та іншу легеневу патологію, $€$ ефективним методом лікування. Спеціалісти центру на високому рівні виконують оперативні втручання з приводу як туберкульозу, так і онкології та вроджених вад. Використання мініінвазивних втручань $\epsilon$ найприйнятнішим у дітей, імплантація внутрішньовенних порт-систем дає змогу покращити прихильність до лікування та зменшити фізичний і психологічний дискомфорт дитини. 